\title{
Marrucciite, a rare Hg-sulfosalt from the Gelnica ore deposit (Slovak Republic), and its comparison with the type occurrence at Buca della Vena mine (Italy)
}

\author{
Jiří SEJKORA ${ }^{1, *}$, Daniel OZDíN², František LAUFEK ${ }^{3}$, Jakub PLÁŠIL ${ }^{1,4}$, Jiří LITOCHLEB ${ }^{1}$ \\ ${ }^{1}$ Department of Mineralogy and Petrology, National Museum, Václavskénám.68, 11579 Prague 1, Czech Republic; jiri_sejkora@nm.cz \\ ${ }^{2}$ Department of Mineralogy and Petrology, Faculty of Natural Sciences, Comenius University, Mlynská Dolina, 84215 Bratislava, \\ Slovak Republic \\ ${ }^{3}$ Czech Geological Survey, Geologická 6, 15200 Prague 5, Czech Republic \\ ${ }^{4}$ Department of Geological Sciences, Faculty of Sciences, Masaryk University, Kotlářská 2, 61137 Brno, Czech Republic \\ * Corresponding author
}

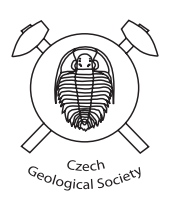

The rare $\mathrm{Hg}$-sulfosalt, marrucciite, with ideal formula $\mathrm{Hg}_{3} \mathrm{~Pb}_{16} \mathrm{Sb}_{18} \mathrm{~S}_{46}$, was found in the Gelnica ore deposit (SpišskoGemerské Rudohorie Mts., Slovak Republic). It occurs as acicular crystals up to $0.5 \mathrm{~mm}$ in length and fine-grained aggregates up to $1 \mathrm{~mm}$ in quartz (+siderite/dolomite) gangue in association with other sulfosalts (zinkenite, scainiite, boulangerite, chalcostibite, bournonite) and cinnabar. It is opaque, dark steel grey to greyish black, sometimes tarnished to a bronze-brown tint, has a dark grey streak with a very weak reddish tint and a metallic luster. Marrucciite is very brittle but thin acicular crystals are flexible. One good cleavage parallel to the elongation of the crystals was observed. The $\mathrm{VHN}_{20 \mathrm{~g}}$ microhardness is $85(69-101) \mathrm{kp} / \mathrm{mm}^{2}$ and corresponds to a Moh's hardness of $c$. 2; the calculated density is $6.00 \mathrm{~g} . \mathrm{cm}^{-3}$. In reflected light, marrucciite is white to greyish white with a weak yellowish tint, distinct bireflectance and white-white grey pleochroism. Under crossed polars, it has distinct anisotropy, with rotation tints in shades of grayish brown and dark brown. Dark red internal reflections were observed only rarely. Marrucciite is monoclinic, space group $C 2 / m$ with $a 48.12(1), b 4.1083(2), c 23.990(5) \AA, \beta 118.76(2)^{\circ}, V 4158$.(3) $\AA^{3}$. Its average composition (electron microprobe data in wt. \%) is $\mathrm{Cu} 0.03, \mathrm{Hg} 7.83, \mathrm{Cd} 0.02, \mathrm{Fe} \mathrm{0.06,} \mathrm{Zn} \mathrm{0.02,} \mathrm{Pb} \mathrm{43.13,} \mathrm{Sn} \mathrm{0.03,} \mathrm{Sb} \mathrm{29.15,} \mathrm{Bi} \mathrm{0.12,} \mathrm{S} \mathrm{19.71,}$ $\mathrm{Cl} 0.05$, total 100.15. The empirical formula on the basis 83 of apfu is $\mathrm{Hg}_{2.93}\left(\mathrm{~Pb}_{15.63} \mathrm{Fe}_{0.08} \mathrm{Cu}_{0.04} \mathrm{Cd}_{0.02} \mathrm{Zn}_{0.02} \mathrm{Sn}_{0.02}\right)_{\Sigma 15.81}$ $\left(\mathrm{Sb}_{17.97} \mathrm{Bi}_{0.04}\right)_{\Sigma 18.01}\left(\mathrm{~S}_{46.14} \mathrm{Cl}_{0.11}\right)_{\Sigma 46.25}$. The crystal structure of marrucciite from Gelnica contains two Hg positions $(6 \mathrm{atoms})$, $7 \mathrm{~Pb}$ positions (28 atoms), $8 \mathrm{Sb}$ positions (32 atoms), two mixed $\mathrm{Pb}-\mathrm{Sb}$ positions (refined as $\mathrm{Pb}_{0.39} \mathrm{Sb}_{0.61}$ and $\mathrm{Pb}_{0.61} \mathrm{Sb}_{0.39}$ ) and $23 \mathrm{~S}$ positions (46 atoms).

Keywords: marrucciite, Hg-sulfosalt, X-ray powder data, electron microanalyses, the Gelnica ore deposit, Slovak Republic Received: 25 May 2011; accepted: 6 December 2011; handling editor: M. Novák

\section{Introduction}

A $\mathrm{Hg}-\mathrm{Pb}$-sulfosalt from the Zenderling occurrence near Gelnica (Slovak Republic) was described for the first time (without a name for the mineral) by Háber and Babčan (1971) and later on (with proposed name gelnicite) by Háber (1980). Háber et al. (2004) again described the material in an abstract, under an unapproved mineral name "gelnicaite?". Descriptions of $\mathrm{Hg}-\mathrm{Pb}$-sulfosalts from Zenderling published in Háber's papers (especially optical properties, hardness and proposed unit-cell parameters) are problematic, confusion with other minerals in close association (namely boulangerite) cannot be excluded. Subsequently, this mineral phase was approved by the Commission on New Minerals, Nomenclature and Classification of the International Mineralogical Association (IMA) as a new mineral - marrucciite - from the $\mathrm{Fe}-\mathrm{Ba}$ deposit at Buca della Vena mine, Apuan Alps, Italy
(Orlandi et al. 2007). This mineral is identical with the $\mathrm{Hg}-\mathrm{Pb}$-sulfosalt from the Zenderling occurrence.

The present study concentrates on our new finds (2002-2004) of marrucciite at Zenderling, where this $\mathrm{Hg}-\mathrm{Pb}$-sulfosalt rarely occurs as well-formed crystals and their aggregates in close association with cinnabar and other sulfosalts. The results of a chemical study confirmed the identity of our mineral phase and the sample described by Háber. The aim of this work is detailed mineralogical characterization of the marrucciite from Zenderling and its comparison to the description of the same mineral from Buca della Vena.

\section{Occurrence and associated minerals}

Mine dumps of the Zenderling deposit (newly designated as the Háj settlement) are located about $1.5 \mathrm{~km} \mathrm{SW}$ of 


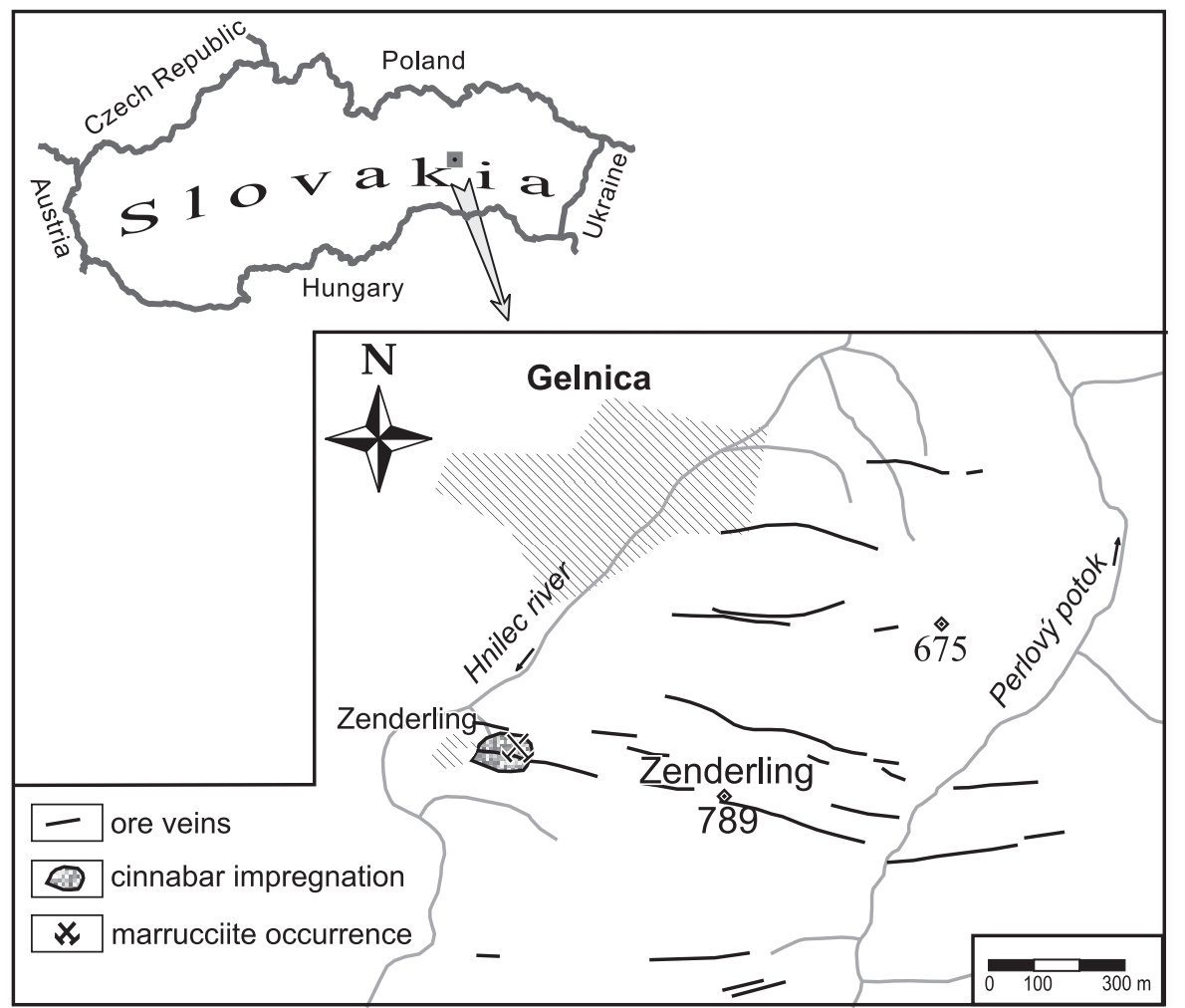

Fig. 1 Topographic sketch of the Zenderling deposit near Gelnica (Slovak Republic) with marked ore veins and place of marrucciite occurrence.
Gelnica (30 km NW of Košice) in the eastern Slovakia, in the Spišsko-Gemerské Rudohorie Mountains (Fig. 1). Mining exploitation of mainly $\mathrm{Ag}, \mathrm{Hg}$ and $\mathrm{Cu}$ ores began in the $13^{\text {th }}$ century. The last mining, geological and metallogenetic research in this area was carried out in the 1960s and 1970s (Háber 1980).

The veinlets-disseminated type of hydrothermal mineralization occurs in porphyroids and rarely in graphitesericite phyllites of the Drnava Complex in the Gelnica Group. The Drnava Complex is an upper lithostratigraphic unit of the Gelnica Group and includes two lydite horizons, volcanoclastic material and metabasalt bodies. The age of the Gelnica Group was determined as Late Cambrian to Early Devonian (Bajaník 1984; Slavkay et al. 2004) on the basis of microflora and acritarchs. The age of the Drnava Complex is considered as Early Devonian (Ivanička et al. 1989).

Hydrothermal veins trend $\mathrm{W}-\mathrm{E}$ and $\operatorname{dip} 45-80^{\circ}$ to the south. The zone of ore veins is $1 \mathrm{~km}$ long and maximum thickness of veins reaches several tens of $\mathrm{cm}$ (Koděra et al. 1986). According to the latest data by Hurai et al. (2002), the age of ore mineralization is Alpine.

The most abundant minerals in this hydrothermal deposit are quartz, siderite and cinnabar. Háber (1980) and Chovan et al. (1994) described also chlorite, rutile, dolomite, ankerite, magnetite, hematite, calcite, muscovite, barite, schorl, dravite, pyrite, chalcopyrite, stibnite, galena and native mercury. Among sulfosalts, the occurrences of tetrahedrite and its variety schwazite, bourno- nite, boulangerite, jamesonite and "gelnicite" (= marrucciite) were described by Háber (1980). During our recent research scainiite, zinkenite, chalcostibite, jordanite and seligmannite were also identified.

Hydrothermal marrucciite is one of the youngest primary minerals in siderite/dolomite-quartz-sulfide veins located in the tectonic zones. Marrucciite occurs in two characteristic mineral assemblages: zinkenite, scainiite, chalcostibite, cinnabar (Fig. 2) and bournonite, boulangerite (Figs 3-5).

\section{Appearance and physical properties}

Marrucciite from Gelnica occurs as acicular crystals, up to $0.5 \mathrm{~mm}$ in length (Fig. 6), sometimes grouped in rich aggregates (Fig. 7); fine-grained aggregates up to $1 \mathrm{~mm}$ across in quartz (+siderite/dolomite) gangue in association with other sulfosalts were also observed (Figs 2-5). It is opaque, dark steel grey to greyish black, sometimes tarnished to a bronze-brown tint, has a dark grey streak with a very weak reddish tint, and a metallic luster. It is not fluorescent in short- or long-wave UV radiation.

Marrucciite is very brittle but the thin acicular crystals are flexible. One good cleavage parallel to the elongation of the crystals was observed. According to Orlandi et al. (2007), the cleavage plane would be (20-1). The fracture is uneven, the $\mathrm{VHN}_{20 \mathrm{~g}}$ microhardness is $85(69-101) \mathrm{kp} /$ $\mathrm{mm}^{2}$ (30 indentations), corresponding to a Moh's hardness 


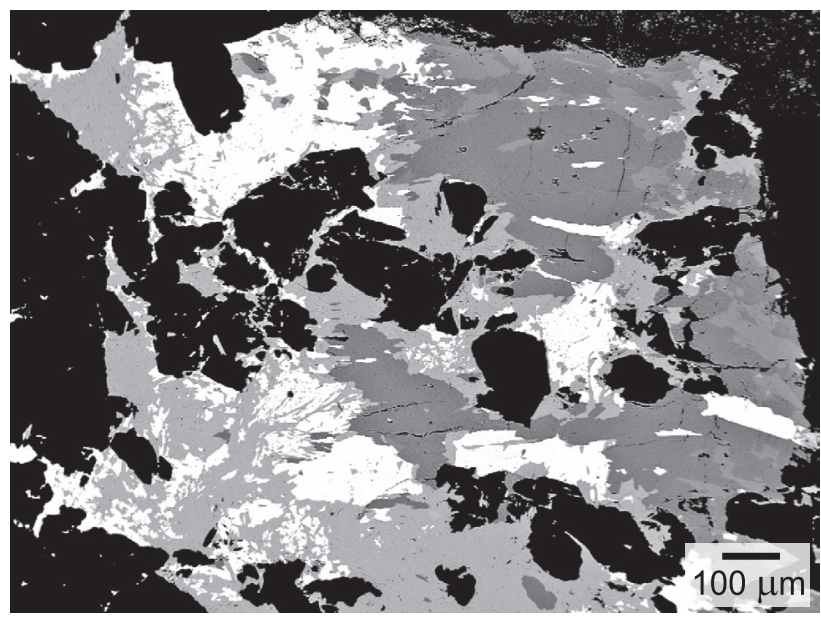

Fig. 2 Marrucciite (light grey) in association with cinnabar (white), scainiite (grey) and zinkenite (dark grey); BSE photo.

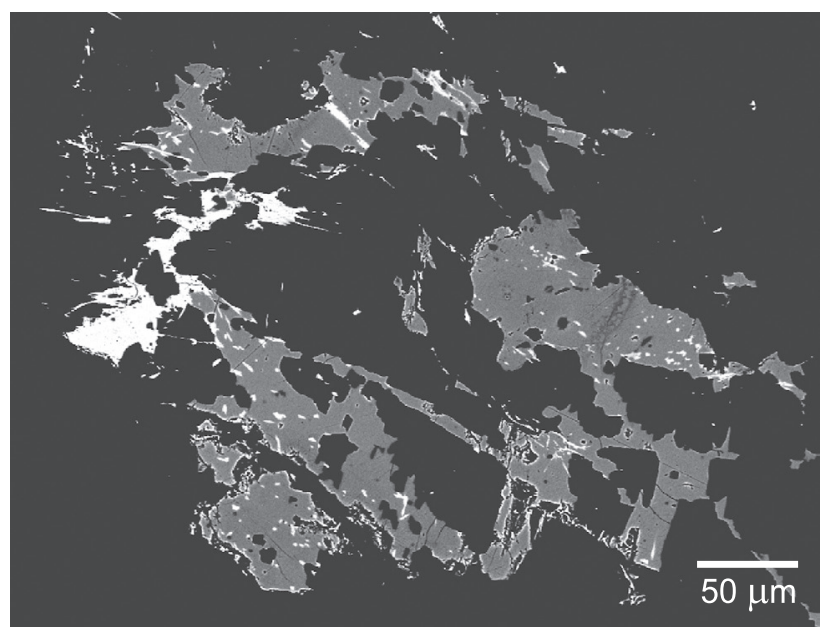

Fig. 4 Bournonite aggregates (grey) are crossed and overgrown by genetically younger marrucciite (white) in dolomite (black); BSE photo.

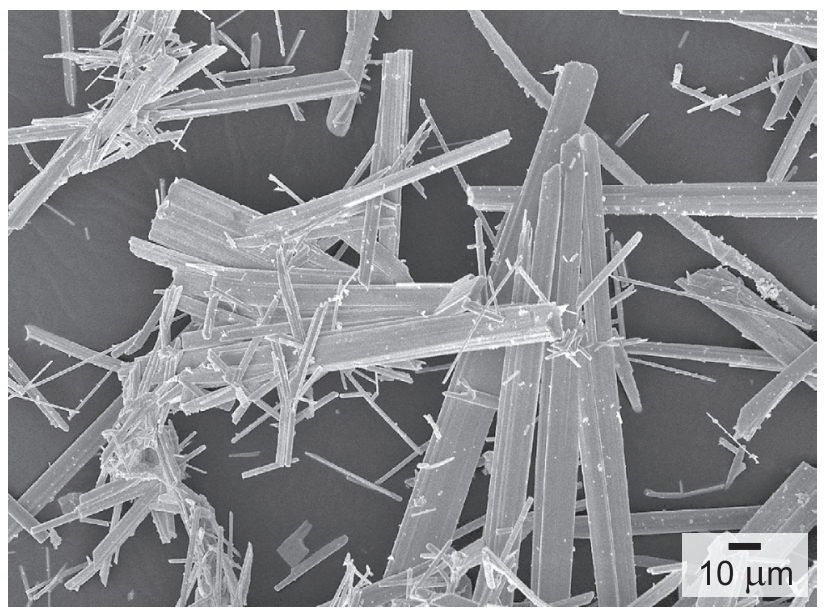

Fig. 6 Group of acicular marrucciite crystals; SEM photo

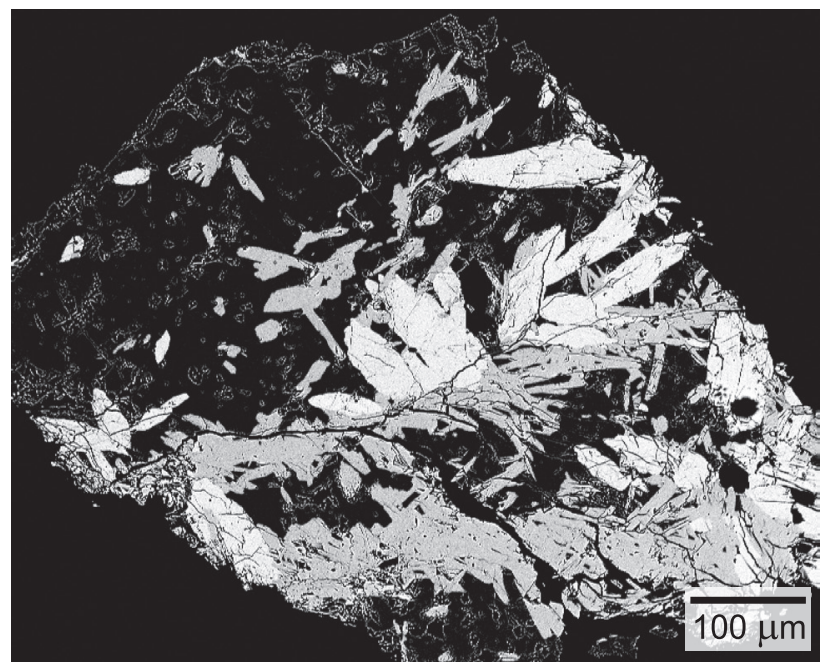

Fig. 3 Thin veins of marrucciite (grey) grown on boulangerite (white) needles in bournonite (dark); BSE photo.

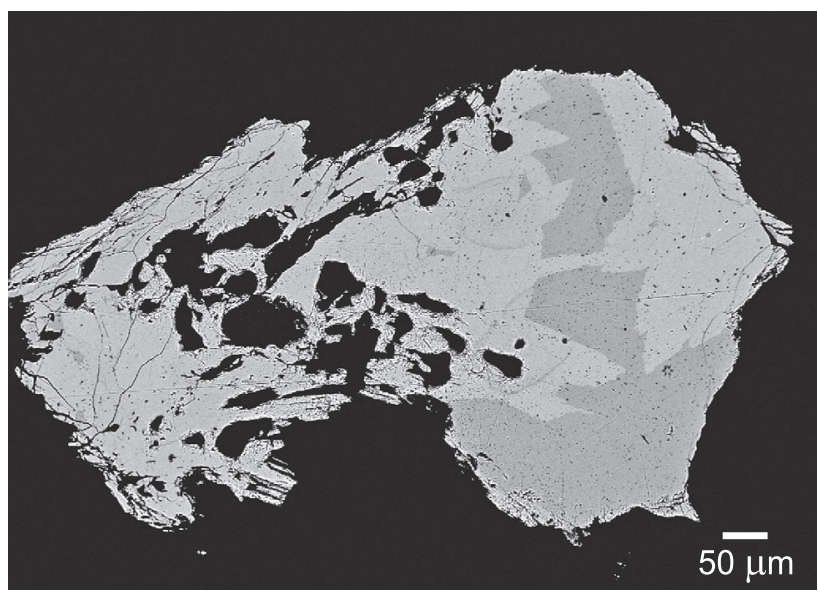

Fig. 5 Boulangerite aggregate (light) with marrucciite relics (darker) in quartz gangue; BSE photo.

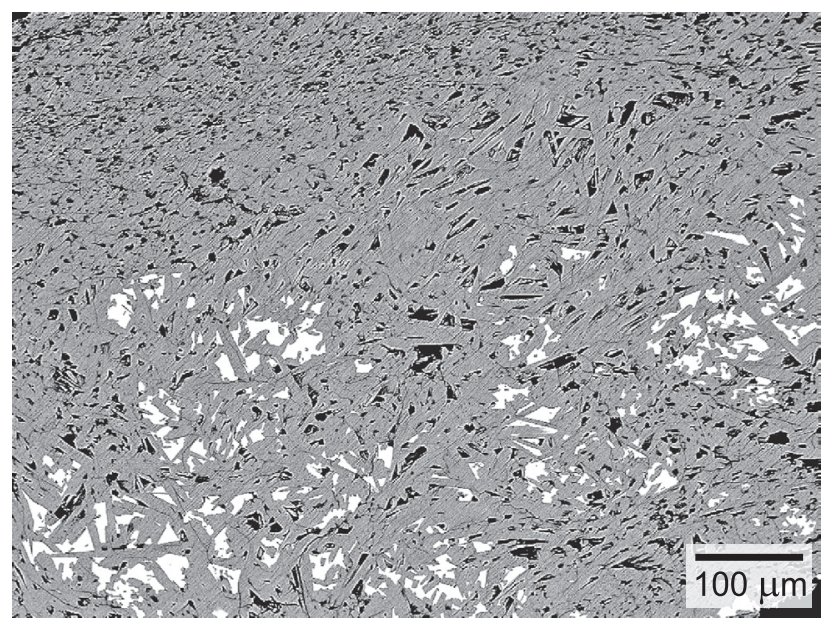

Fig. 7 Intergrowth of acicular marrucciite crystals (grey) with relict grains of cinnabar (white). BSE photo Cameca SX 100. 


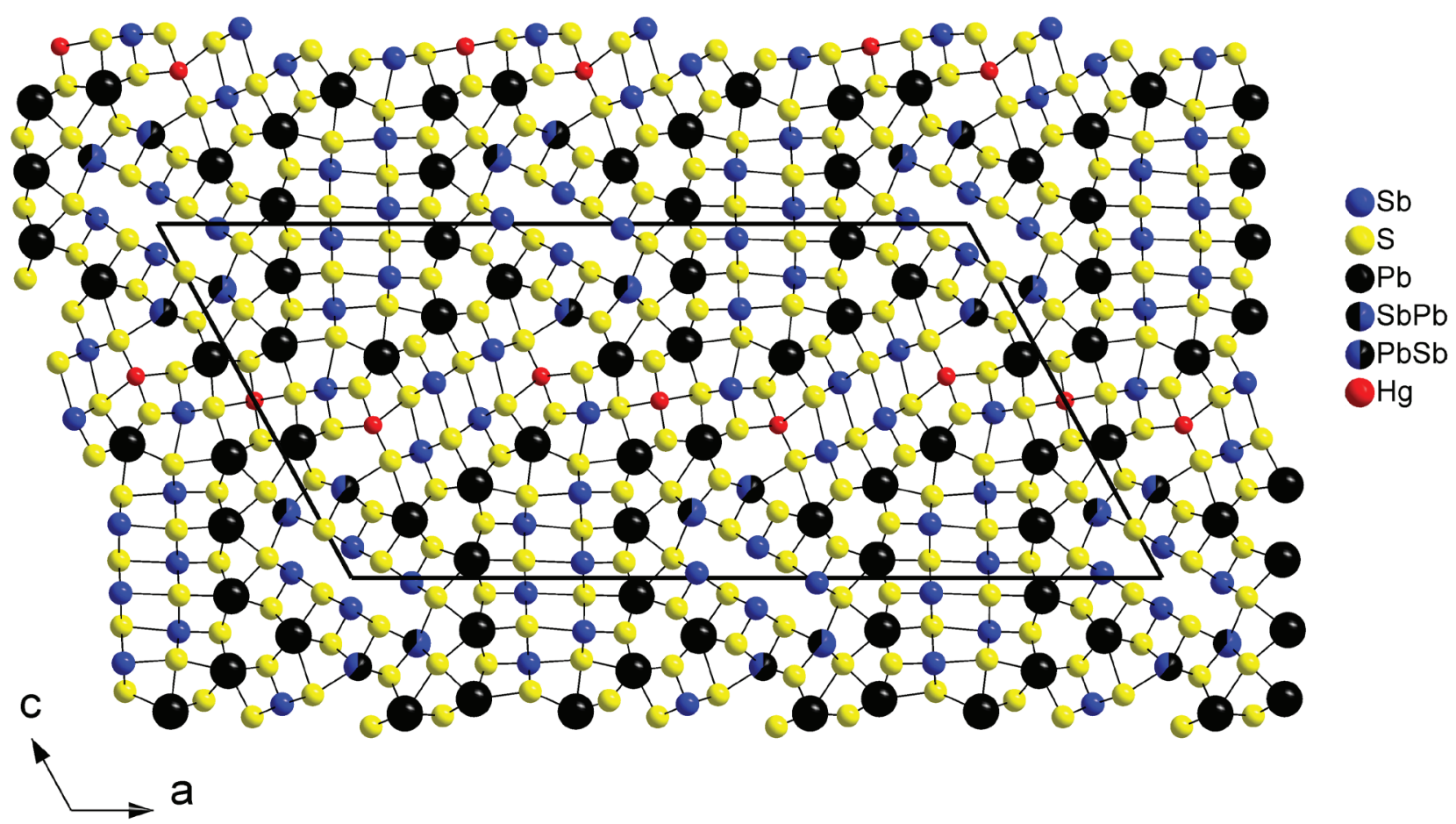

Fig. 8 Projection of the marrucciite crystal structure along b axis. Unit cell is outlined. Based on the data of Laufek et al. (2007).

of $c$. 2. Density could not be measured directly due to the small grain size; the value of $6.00 \mathrm{~g} . \mathrm{cm}^{-3}$ was calculated on the basis of the empirical formula and unit-cell parameters refined from X-ray powder data. This is very close to the

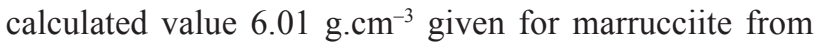
Buca della Vena mine by Orlandi et al. (2007).

The sample of marrucciite from Gelnica was prepared for optical investigation using standard diamond polishing techniques. In plane-polarized reflected light (from an unfiltered quartz-halogen lamp at about $3100 \mathrm{~K}$ ), marrucciite is white to greyish white with a weak yellowish tint, distinct bireflectance and white-white grey pleochroism. Under crossed polars, marrucciite has a distinct anisotropy with rotation tints in shades of greyish brown and dark brown. Dark red internal reflections were observed only rarely. Orlandi et al. (2007) reported for marrucciite from Buca della Vena mine a light grey color without pleochroism and for sub-longitudinal sections a distinct anisotropy without marked polarization tints (dark blue to dark brown).

\section{Crystallography}

The crystal structure of marrucciite from Buca della Vena was solved and refined to a $\mathrm{R}$ factor of $9.56 \%$ by Orlandi et al. (2007). Discovery of crystals of this sulfosalt in Gelnica allowed Laufek et al. (2007) a more precise structure refinement to a $\mathrm{R}$ factor of $2.46 \%$.
The structure model proposed by Orlandi et al. (2007) was in principle confirmed. Marrucciite crystallizes in space group $C 2 / \mathrm{m}$. The unit-cell of marrucciite (Fig. 8) contains two $\mathrm{Hg}$ positions (6 atoms), $7 \mathrm{~Pb}$ positions (28 atoms), $8 \mathrm{Sb}$ positions (32 atoms), two mixed $\mathrm{Pb}-\mathrm{Sb}$ positions (refined as $\mathrm{Pb}_{0.39} \mathrm{Sb}_{0.61}$ and $\mathrm{Pb}_{0.61} \mathrm{Sb}_{0.39}$ ) and 23 $\mathrm{S}$ positions (46 atoms). The crystal structure-derived formula, based on the refinement of Laufek et al. (2007), is $\mathrm{Hg}_{3} \mathrm{~Pb}_{16} \mathrm{Sb}_{18} \mathrm{~S}_{46}$.

The major difference between the two refinements of marrucciite from Gelnica and Buca della Vena is the absence of the rare and weak $2 b$ superstructure diffraction spots in the former. These weak reflections indicate a weak $\sim 8 \AA$ superstructure along the $b$ direction in the Buca della Vena material, which modifies the $4 \AA$ submotif by split positions of some $\mathrm{Sb}$ sites. Splitting of adjacent $\mathrm{S}$ positions was also observed (Orlandi et al. 2007). As was mentioned above, no $2 b$ superstructure reflections were detected for marrucciite from Gelnica. Consequently, no split positions with a half-occupancy were determined in the crystal structure of marrucciite from Gelnica (Laufek et al. 2007). On the other hand, both marrucciite samples show two $\mathrm{Pb}-\mathrm{Sb}$ mixed positions with approximately identical occupancy factors of $\mathrm{Pb}$ and $\mathrm{Sb}$. Noteworthy is that many sulfosalts from Buca della Vena (e.g. scainiite, pillaite, pellouxite) show very weak $8 \AA$ superstructure reflections. However, with the exception of scainiite (Moëlo et al. 2000), they are too weak to be fully exploited in the crystal structure analysis. 
Tab. 1 X-ray powder diffraction pattern of marrucciite from Gelnica

\begin{tabular}{|c|c|c|c|c|c|c|c|c|c|c|c|c|c|c|c|c|c|}
\hline $\mathrm{I} / \mathrm{I}_{\mathrm{o}}$ & $\mathrm{d}_{\text {obs. }}$ & $\mathrm{d}_{\text {calc. }}$ & $\mathrm{h}$ & $\mathrm{k}$ & 1 & $\mathrm{I} / \mathrm{I}_{\mathrm{o}}$ & $\mathrm{d}_{\text {obs. }}$ & $\mathrm{d}_{\text {calc. }}$ & $\mathrm{h}$ & $\mathrm{k}$ & 1 & $\mathrm{I} / \mathrm{I}_{\mathrm{o}}$ & $\mathrm{d}_{\mathrm{obs} .}$ & $\mathrm{d}_{\text {calc. }}$ & $\mathrm{h}$ & $\mathrm{k}$ & \\
\hline \multirow[t]{2}{*}{2} & 20.90 & 21.07 & 2 & 0 & 0 & 1 & 3.080 & 3.080 & 7 & 1 & -5 & 2 & 2.1805 & 2.1805 & 9 & 1 & 5 \\
\hline & & 21.02 & 0 & 0 & 1 & 11 & 3.056 & 3.057 & 8 & 0 & 4 & 5 & 2.1651 & 2.1655 & 18 & 0 & -10 \\
\hline 1 & 20.57 & 20.66 & 2 & 0 & -1 & 3 & 3.022 & 3.015 & 5 & 1 & 3 & & & 2.1648 & 1 & 1 & 8 \\
\hline 4 & 12.199 & 12.229 & 2 & 0 & 1 & 35 & 3.003 & 3.004 & 16 & 0 & -4 & 1 & 2.1352 & 2.1362 & 17 & 1 & -8 \\
\hline 5 & 11.990 & 12.016 & 4 & 0 & -1 & & & 3.001 & 1 & 1 & -5 & 4 & 2.1267 & 2.1265 & 22 & 0 & -3 \\
\hline 1 & 10.518 & 10.537 & 4 & 0 & 0 & & & 3.000 & 7 & 1 & 2 & 7 & 2.1192 & 2.1192 & 15 & 1 & -9 \\
\hline 2 & 10.306 & 10.329 & 4 & 0 & -2 & 11 & 2.9956 & 2.9964 & 8 & 0 & -8 & 6 & 2.1013 & 2.1020 & 0 & 0 & 10 \\
\hline 2 & 7.998 & 8.003 & 4 & 0 & 1 & 12 & 2.9803 & 2.9806 & 11 & 1 & -2 & 3 & 2.0966 & 2.0963 & 15 & 1 & 2 \\
\hline \multirow[t]{2}{*}{13} & 7.825 & 7.836 & 6 & 0 & -2 & 5 & 2.9619 & 2.9670 & 3 & 1 & 4 & 4 & 2.0692 & 2.0685 & 22 & 0 & -2 \\
\hline & & 7.822 & 4 & 0 & -3 & 6 & 2.9358 & 2.9382 & 11 & 1 & -4 & 6 & 2.0659 & 2.0659 & 20 & 0 & -10 \\
\hline \multirow[t]{2}{*}{2} & 7.017 & 7.025 & 6 & 0 & 0 & 15 & 2.9143 & 2.9146 & 11 & 1 & -1 & & & 2.0617 & 3 & 1 & 8 \\
\hline & & 7.007 & 0 & 0 & 3 & 9 & 2.8952 & 2.8975 & 4 & 0 & -8 & 4 & 2.0528 & 2.0534 & 0 & 2 & 0 \\
\hline 1 & 6.883 & 6.886 & 6 & 0 & -3 & 12 & 2.8636 & 2.8646 & 1 & 1 & 5 & 2 & 2.0302 & 2.0316 & 19 & 1 & -8 \\
\hline 1 & 6.112 & 6.115 & 4 & 0 & 2 & 11 & 2.8561 & 2.8543 & 7 & 1 & -6 & 6 & 2.0282 & 2.0299 & 17 & 1 & 1 \\
\hline 2 & 6.004 & 6.008 & 8 & 0 & -2 & 3 & 2.8379 & 2.8369 & 11 & 1 & -5 & 9 & 1.9976 & 1.9961 & 7 & 1 & 7 \\
\hline 1 & 5.982 & 5.993 & 4 & 0 & -4 & 11 & 2.8007 & 2.8017 & 11 & 1 & 0 & 0 & 1.9976 & 1.9968 & 22 & 0 & -1 \\
\hline \multirow[t]{2}{*}{5} & 5.858 & 5.868 & 6 & 0 & 1 & 0 & 2.8007 & 2.7981 & 9 & 1 & -6 & 2 & 1.9910 & 1.9900 & 21 & 1 & -4 \\
\hline & & 5.858 & 2 & 0 & 3 & 2 & 2.7746 & 2.7730 & 7 & 1 & 3 & 4 & 1.9608 & 1.9616 & 22 & 0 & -10 \\
\hline 3 & 5.737 & 5.742 & 8 & 0 & -3 & 1 & 2.7575 & 2.7598 & 5 & 1 & 4 & & & 1.9607 & 20 & 0 & -11 \\
\hline 1 & 5.246 & 5.255 & 0 & 0 & 4 & 2 & 2.7474 & 2.7479 & 13 & 1 & -3 & & & 1.9607 & 19 & 1 & -9 \\
\hline 1 & 5.166 & 5.165 & 8 & 0 & -4 & 2 & 2.7222 & 2.7235 & 1 & 1 & -6 & 3 & 1.9532 & 1.9528 & 6 & 0 & 9 \\
\hline 4 & 4.787 & 4.788 & 10 & 0 & -2 & 6 & 2.7109 & 2.7123 & 10 & 0 & 4 & 2 & 1.9383 & 1.9375 & 24 & 0 & -3 \\
\hline 3 & 4.750 & 4.753 & 6 & 0 & -5 & & & 2.7112 & 8 & 0 & 5 & 3 & 1.9313 & 1.9317 & 6 & 0 & -12 \\
\hline 1 & 4.606 & 4.605 & 2 & 0 & 4 & 5 & 2.6688 & 2.6686 & 13 & 1 & -5 & & & 1.9319 & 17 & 1 & 2 \\
\hline 5 & 4.578 & 4.579 & 10 & 0 & -1 & 3 & 2.6645 & 2.6615 & 8 & 0 & -9 & 1 & 1.9144 & 1.9139 & 13 & 1 & -11 \\
\hline 3 & 4.559 & 4.566 & 2 & 0 & -5 & 3 & 2.6535 & 2.6574 & 11 & 1 & 1 & 2 & 1.9129 & 1.9113 & 18 & 0 & -12 \\
\hline 5 & 4.201 & 4.204 & 0 & 0 & 5 & & & 2.6548 & 10 & 0 & -9 & 2 & 1.9051 & 1.9058 & 1 & 1 & -10 \\
\hline 21 & 4.075 & 4.076 & 6 & 0 & 3 & 2 & 2.6267 & 2.6275 & 0 & 0 & 8 & 3 & 1.8795 & 1.8797 & 14 & 0 & 6 \\
\hline \multirow[t]{4}{*}{26} & 3.997 & 4.005 & 12 & 0 & -3 & 4 & 2.6020 & 2.6049 & 9 & 1 & -7 & & & 1.8792 & 12 & 0 & 7 \\
\hline & & 4.002 & 8 & 0 & 2 & & & 2.6007 & 1 & 1 & 6 & 5 & 1.8717 & 1.8719 & 19 & 1 & 1 \\
\hline & & 3.997 & 4 & 0 & 4 & 1 & 2.5627 & 2.5611 & 3 & 1 & -7 & & & 1.8712 & 21 & 1 & -9 \\
\hline & & 3.995 & 6 & 0 & -6 & & & 2.5621 & 18 & 0 & -2 & 5 & 1.8618 & 1.8612 & 23 & 1 & -6 \\
\hline \multirow[t]{2}{*}{2} & 3.970 & 3.978 & 1 & 1 & 1 & 2 & 2.5532 & 2.5545 & 4 & 0 & -9 & 4 & 1.8489 & 1.8489 & 7 & 1 & 8 \\
\hline & & 3.973 & 3 & 1 & -1 & & & 2.5525 & 7 & 1 & 4 & 3 & 1.8401 & 1.8405 & 14 & 0 & -13 \\
\hline \multirow[t]{2}{*}{3} & 3.949 & 3.951 & 12 & 0 & -2 & 4 & 2.5246 & 2.5251 & 14 & 0 & -9 & 5 & 1.8336 & 1.8339 & 6 & 2 & 3 \\
\hline & & 3.942 & 3 & 1 & 0 & 1 & 2.4977 & 2.4974 & 11 & 1 & 2 & & & 1.8328 & 17 & 1 & 3 \\
\hline 4 & 3.912 & 3.911 & 8 & 0 & -6 & 1 & 2.4811 & 2.4814 & 15 & 1 & -2 & 4 & 1.8253 & 1.8263 & 6 & 2 & -6 \\
\hline \multirow[t]{2}{*}{2} & 3.867 & 3.871 & 1 & 1 & -2 & 1 & 2.4717 & 2.4713 & 16 & 0 & 1 & & & 1.8257 & 2 & 0 & 11 \\
\hline & & 3.866 & 3 & 1 & -2 & & & 2.4658 & 2 & 0 & 8 & 2 & 1.8180 & 1.8181 & 8 & 2 & -6 \\
\hline 7 & 3.795 & 3.796 & 10 & 0 & 1 & 2 & 2.4534 & 2.4542 & 2 & 0 & -9 & 9 & 1.7925 & 1.7934 & 13 & 1 & -12 \\
\hline 5 & 3.786 & 3.783 & 3 & 1 & 1 & & & 2.4507 & 13 & 1 & -7 & & & 1.7920 & 24 & 0 & -11 \\
\hline \multirow[t]{2}{*}{1} & 3.759 & 3.761 & 2 & 0 & -6 & 1 & 2.4439 & 2.4459 & 10 & 0 & 5 & 2 & 1.7691 & 1.7688 & 8 & 2 & 3 \\
\hline & & 3.751 & 1 & 1 & 2 & 4 & 2.3945 & 2.3920 & 5 & 1 & -8 & 2 & 1.7640 & 1.7634 & 7 & 1 & -12 \\
\hline 17 & 3.712 & 3.714 & 12 & 0 & -5 & & & 2.3939 & 20 & 0 & -4 & 4 & 1.7609 & 1.7616 & 14 & 2 & -3 \\
\hline 5 & 3.691 & 3.692 & 5 & 1 & 0 & 1 & 2.3555 & 2.3558 & 9 & 1 & 4 & & & 1.7603 & 6 & 2 & -7 \\
\hline 4 & 3.650 & 3.653 & 3 & 1 & -3 & & & 2.3546 & 20 & 0 & -3 & & & 1.7598 & 14 & 2 & -4 \\
\hline 1 & 3.519 & 3.520 & 7 & 1 & -2 & 7 & 2.3349 & 2.3367 & 3 & 1 & -8 & 4 & 1.7418 & 1.7413 & 16 & 0 & 6 \\
\hline 80 & 3.481 & 3.483 & 8 & 0 & 3 & 3 & 2.3157 & 2.3166 & 13 & 1 & -8 & 2 & 1.7352 & 1.7357 & 25 & 1 & -5 \\
\hline
\end{tabular}


Tab. 1 - continued

\begin{tabular}{|c|c|c|c|c|c|c|c|c|c|c|c|c|c|c|c|c|c|}
\hline $\mathrm{I} / \mathrm{I}_{\mathrm{o}}$ & $\mathrm{d}_{\mathrm{obs} .}$ & $\mathrm{d}_{\text {calc. }}$ & $\mathrm{h}$ & $\mathrm{k}$ & 1 & $\mathrm{I} / \mathrm{I}_{\mathrm{o}}$ & $\mathrm{d}_{\mathrm{obs} .}$ & $\mathrm{d}_{\text {calc. }}$ & $\mathrm{h}$ & $\mathrm{k}$ & 1 & $\mathrm{I} / \mathrm{I}_{\mathrm{o}}$ & $\mathrm{d}_{\mathrm{obs} .}$ & $\mathrm{d}_{\text {calc. }}$ & $\mathrm{h}$ & $\mathrm{k}$ & 1 \\
\hline 26 & 3.428 & 3.428 & 14 & 0 & -3 & 1 & 2.3091 & 2.3099 & 5 & 1 & 6 & & & 1.7340 & 21 & 1 & 1 \\
\hline \multirow[t]{2}{*}{100} & 3.415 & 3.419 & 6 & 0 & -7 & 4 & 2.2952 & 2.2954 & 18 & 0 & -9 & 3 & 1.7222 & 1.7216 & 24 & 0 & -12 \\
\hline & & 3.415 & 14 & 0 & -4 & 2 & 2.2804 & 2.2828 & 4 & 0 & -10 & 3 & 1.7170 & 1.7181 & 25 & 1 & -8 \\
\hline 7 & 3.405 & 3.408 & 8 & 0 & -7 & & & 2.2840 & 13 & 1 & 2 & & & 1.7166 & 28 & 0 & -7 \\
\hline 14 & 3.386 & 3.380 & 3 & 1 & -4 & 2 & 2.2705 & 2.2698 & 17 & 1 & -2 & 2 & 1.7034 & 1.7038 & 16 & 0 & -14 \\
\hline 10 & 3.376 & 3.374 & 5 & 1 & -4 & 2 & 2.2466 & 2.2470 & 3 & 1 & 7 & & & 1.7046 & 8 & 2 & 4 \\
\hline 19 & 3.356 & 3.353 & 14 & 0 & -2 & 1 & 2.2332 & 2.2346 & 9 & 1 & -9 & 2 & 1.6949 & 1.6952 & 16 & 2 & -4 \\
\hline 19 & 3.340 & 3.343 & 4 & 0 & -7 & & & 2.2334 & 15 & 1 & -8 & & & 1.6938 & 8 & 2 & -8 \\
\hline 21 & 3.316 & 3.317 & 14 & 0 & -5 & 7 & 2.2059 & 2.2114 & 15 & 1 & 1 & 2 & 1.6800 & 1.6808 & 5 & 1 & 10 \\
\hline \multirow[t]{2}{*}{6} & 3.253 & 3.255 & 9 & 1 & -2 & & & 2.2080 & 2 & 0 & 9 & 3 & 1.6767 & 1.6754 & 4 & 2 & -8 \\
\hline & & 3.253 & 3 & 1 & 3 & & & 2.2045 & 17 & 1 & -1 & 3 & 1.6750 & 1.6744 & 15 & 1 & -13 \\
\hline 4 & 3.193 & 3.195 & 2 & 0 & -7 & & & 2.2049 & 20 & 0 & -1 & 1 & 1.6577 & 1.6572 & 13 & 1 & 7 \\
\hline 6 & 3.153 & 3.156 & 1 & 1 & 4 & 4 & 2.1978 & 2.1936 & 5 & 1 & -9 & & & & & & \\
\hline 4 & 3.130 & 3.131 & 9 & 1 & -4 & & & 2.1941 & 8 & 0 & 7 & & & & & & \\
\hline 2 & 3.085 & 3.088 & 9 & 1 & 0 & 2 & 2.1855 & 2.1844 & 22 & 0 & -5 & & & & & & \\
\hline
\end{tabular}

Tab. 2 Unit-cell parameters of marrucciite (for monoclinic space group $\mathrm{C} 2 / \mathrm{m}$ )

\begin{tabular}{|c|c|c|c|c|c|c|}
\hline & & $a[\AA]$ & $b[\AA]$ & $c[\AA]$ & $\beta\left[^{\circ}\right]$ & $V\left[\AA^{3}\right]$ \\
\hline powder & this paper & $48.077(8)$ & $4.1068(6)$ & $23.976(3)$ & $118.752(8)$ & $4150 .(1)$ \\
\hline single & Laufek et al. (2007) & $48.12(1)$ & $4.1083(2)$ & $23.990(5)$ & $118.76(2)$ & 4158.(1) \\
\hline single & Orlandi et al. (2007) & $48.32(1)$ & $4.1170(8)$ & $24.056(5)$ & $118.84(3)$ & 4192.(1) \\
\hline powder & Orlandi et al. (2007) & $48.32(1)$ & $4.117(1)$ & $24.056(5)$ & $118.84(3)$ & 4192.(3) \\
\hline
\end{tabular}

Calculated, after Orlandi et al. (2007)

Calculated, after Laufek et al. (2007)

Debye-Scherrer, Gelnica sample

Bragg-Brentano, Gelnica sample

T Gandolfi camera, Orlandi et al. (2007)

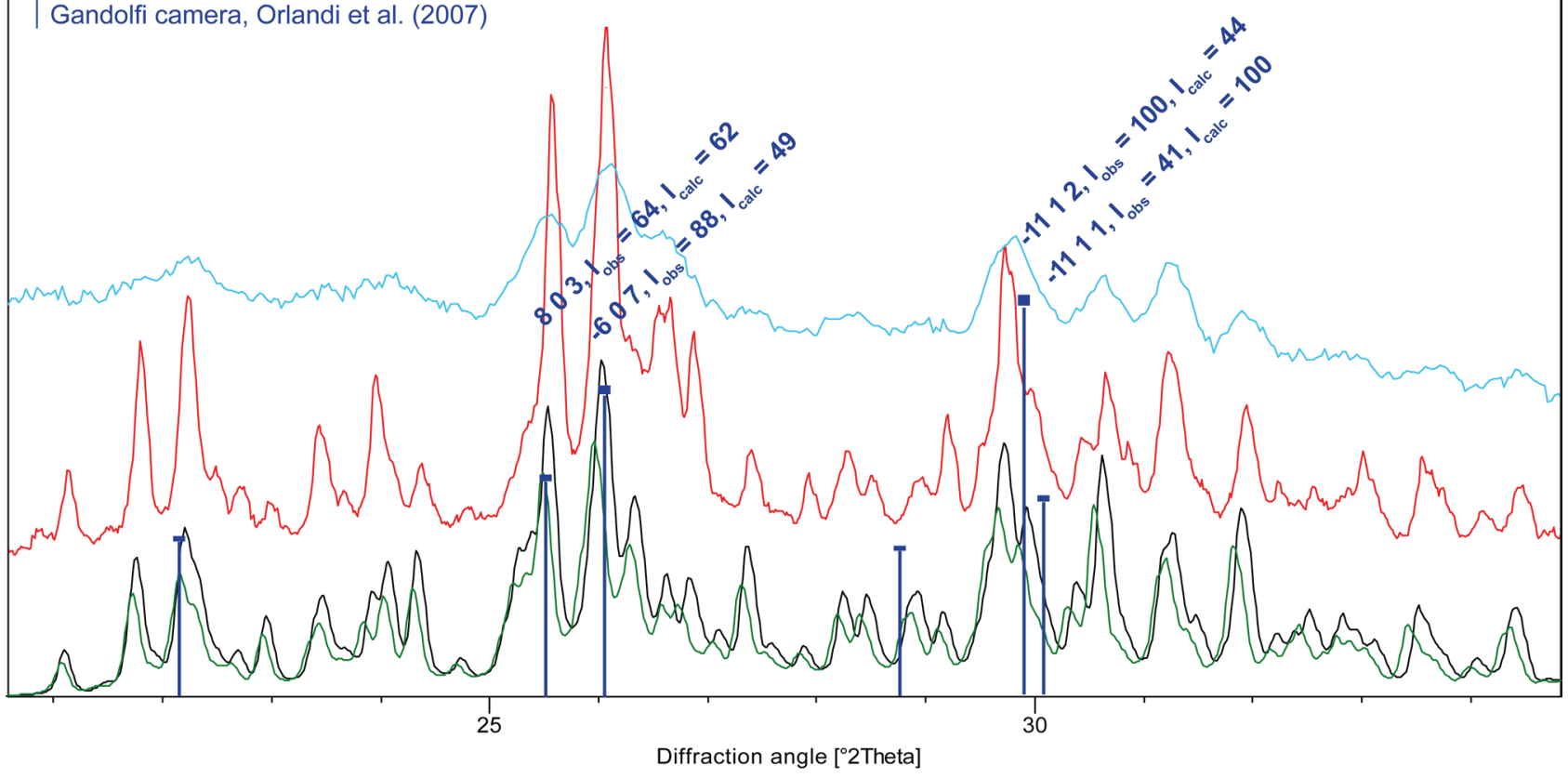

Fig. 9 A comparison of powder diffraction patterns of marrucciite from Gelnica with the previously published data. The values for the four diffractions of the highest intensity by Orlandi et al. (2007) are indicated. 
A handpicked sample of marrucciite from Gelnica was used to collect the X-ray powder diffraction patterns. First, a PANalytical X'Pert Pro powder diffractometer $(40 \mathrm{kV} / 30 \mathrm{nA})$ with $\mathrm{X}^{\prime}$ Celerator solid-state detector operating in Bragg-Brentano geometry using monochromatic $\mathrm{Cu} K_{\alpha 1,2}$ radiation $(\lambda=1.54178 \AA)$ was utilized. To minimize the complicated shape of the background, the powder sample was placed onto a flat low-background silicon wafer. The powder pattern was collected in the range from 2 to $90^{\circ} 2 \theta$ with a step size of $0.017^{\circ} 2 \theta$ and integrated exposure time of $500 \mathrm{~s}$ per step (total collection time $\sim 10$ hours) (Tab. 1). The positions and intensities of diffractions were found and refined using the Pearson VII profile-shape function with the ZDS program package (Ondruš 1995) and the unit-cell parameters were refined by the least-squares algorithm implemented by Burnham (1962). Due to some obvious discrepancies between experimental data and powder pattern calculated by Laufek et al. (2007) from the crystal structure using Lazy Pulverix (Yvon et al. 1977) and PowderCell (Kraus and Nolze 2000), a second diffraction experiment involving a different geometry of the diffractometer (Debye-Scherrer) was carried out. For this purpose a PANalytical X'Pert Pro powder diffractometer was utilized. The small amount of marrucciite powder was placed onto a glass fiber, mounted on a goniometric head and scanned using a nearly linear X-ray beam, provided by a $300 \mu \mathrm{m}$ capillary. In order to improve the counting statistics, the secondary monochromator was not used. The radiation was Ni-filtered. The powder pattern was collected in the range from 3 to $90^{\circ}$ $2 \theta$ with a step size of $0.033^{\circ} 2 \theta$ and a counting time 3000 $\mathrm{s}$ (yielding a total data collection time of $\sim 3$ days).

An overview of the refined unit-cell parameters for marrucciite from both occurrences is given in Tab. 2. As has been mentioned above, there are considerable discrepancies between experimental and calculated powder patterns, namely between that from the refined structure by Laufek et al. (2007) and the experimental powder pattern reported by Orlandi et al. (2007). For clarity, all data discussed are displayed in Fig. 9. First, the shift between patterns calculated from the structure data of Laufek et al. (2007) and Orlandi et al. (2007) is caused by different unit-cell volumes, 4158.2(15) and 4192(3) $\AA$, respectively. Further, there are a few mismatches between the calculated intensities of some diffractions in the two powder patterns. The main discrepancy, as was mentioned above, is between the powder data reported by Orlandi et al. (2007), their own results of structural refinement (calculated powder pattern), results of Laufek et al. (2007) and currently presented experimental powder diffraction data. The diffraction with the highest intensity in the experimental powder pattern of Orlandi et al. (2007) is -1112 and a second one of high intensity is $-607\left(_{\text {rel }}\right.$ $=88$ ). According to the structural model of Orlandi et al. (2007), the former should have an intensity of 44 and the latter of 64. It is a question, why Orlandi et al. (2007) reported as the diffraction of the highest calculated intensity, -1111 at $30.63^{\circ} 2 \theta$, because from their own structural model it should have $I_{\text {rel }}=89$. Why there are such differences between the experimental powder pattern of Orlandi et al. (2007) and their own structural model on the one hand, and our data and calculated pattern on the other, is not clear. The currently presented powder diffraction data are quite homogeneous (overall intensity agreement of both diffraction geometries). Orlandi et al. (2007) suggested that these problems arose from various causes such as fibrous habit of the crystals, long-range disorder at the crystal scale, and consequently bad quality of the crystal structure refinement. Based on the current results, such explanations seem unlikely.

\section{Chemical composition}

Quantitative chemical analyses of marrucciite from Gelnica were carried out by means of a Cameca SX 100 electron microprobe in wavelength-dispersive mode (State Geological Institute of Dionýz Štúr, Bratislava), using an acceleration voltage of $20 \mathrm{kV}$, a sample current of 15-20 nA and a beam diameter of 3-8 $\mu \mathrm{m}$. The following standards and spectral lines were employed: $\mathrm{PbS}(\mathrm{Pb}$ $\left.\left.\mathrm{M}_{\alpha}\right), \mathrm{CuFeS}_{2}(\mathrm{Cu}, \mathrm{Fe}, \mathrm{S} \mathrm{K})_{\alpha}\right), \mathrm{ZnS}(\mathrm{Zn}$ $\left.\mathrm{K}_{\alpha}\right), \mathrm{Sb}_{2} \mathrm{~S}_{3}\left(\mathrm{Sb} \mathrm{L}_{\beta}\right), \operatorname{Ag}\left(\mathrm{Ag} \mathrm{L}_{\alpha}\right), \mathrm{Cd}(\mathrm{Cd}$ $\left.\mathrm{L}_{\alpha}\right), \mathrm{Bi}\left(\mathrm{Bi} \mathrm{L}_{\alpha}\right), \mathrm{HgS}\left(\mathrm{Hg} \mathrm{L}_{\alpha}\right), \mathrm{SnO}_{2}$ $\left(\mathrm{Sn} \mathrm{L}_{\beta}\right), \mathrm{FeAsS}\left(\mathrm{As} \mathrm{K} \mathrm{K}_{\beta}\right)$, PbSe $\left(\mathrm{Se} \mathrm{L}_{\beta}\right)$ and $\mathrm{NaCl}\left(\mathrm{Cl} \mathrm{K}_{\alpha}\right) ; \beta$ lines for $\mathrm{Sb}, \mathrm{Sn}$, As and Se were used to solve overlaps problems. The contents of Ag, As and Se were sought but not detected (detection limit close to $0.01-0.05$ wt. \%).

Representative analyses of marrucciite from Gelnica are given in Tab. 3, 
Tab. 4 Comparison of chemical composition of marrucciite from Gelnica and Buca della Vena (wt. \%)

\begin{tabular}{lrrrrrrr}
\hline & \multicolumn{2}{c}{ Gelnica $^{1}$} & \multicolumn{2}{c}{ Buca della Vena $^{2}$} & \multicolumn{2}{c}{ Buca della Vena $^{3}$} & ideal $^{4}$ \\
\hline & \multicolumn{1}{c}{ mean } & \multicolumn{1}{c}{ range } & mean & \multicolumn{1}{c}{ range } & mean & range & \\
\hline $\mathrm{Fe}$ & 0.06 & $0.00-0.41$ & & & & & \\
$\mathrm{~Pb}$ & 43.13 & $41.59-44.42$ & 42.17 & $41.98-42.37$ & 42.41 & $42.34-42.51$ & 43.71 \\
$\mathrm{Cd}$ & 0.02 & $0.00-0.07$ & & & & & \\
$\mathrm{Zn}$ & 0.02 & $0.00-0.07$ & & & & & \\
$\mathrm{Sn}$ & 0.03 & $0.00-0.08$ & & & & & \\
$\mathrm{Hg}$ & 7.83 & $7.27-8.38$ & 7.73 & $7.25-8.29$ & 7.90 & $7.78-7.98$ & 7.94 \\
$\mathrm{Cu}$ & 0.03 & $0.00-0.31$ & 0.09 & $0.00-0.27$ & 0.18 & $0.08-0.34$ & \\
$\mathrm{Sb}$ & 29.15 & $28.29-30.16$ & 28.96 & $28.79-29.22$ & 29.71 & $29.65-29.79$ & 28.90 \\
$\mathrm{Bi}$ & 0.12 & $0.00-0.66$ & & & & & \\
$\mathrm{~S}$ & 19.71 & $19.25-20.06$ & 19.00 & $18.85-19.33$ & 19.47 & $19.22-19.64$ & 19.45 \\
$\mathrm{Cl}$ & 0.05 & $0.03-0.10$ & 0.06 & $0.00-0.15$ & 0.02 & $0.04-0.08$ & \\
\hline total & 100.15 & $98.01-102.37$ & 98.02 & $97.29-98.86$ & 99.73 & $99.53-99.83$ & 100.00 \\
\hline
\end{tabular}

${ }^{1} 25$ analyses in 7 independent samples (this paper); ${ }^{2} 7$ analyses in sample A (Orlandi et al. 2007); ${ }^{3} 4$ analyses in sample B (Orlandi et al. 2007); ${ }^{4}$ ideal composition of marrucciite $\mathrm{Hg}_{3} \mathrm{~Pb}_{16} \mathrm{Sb}_{18} \mathrm{~S}_{46}$.

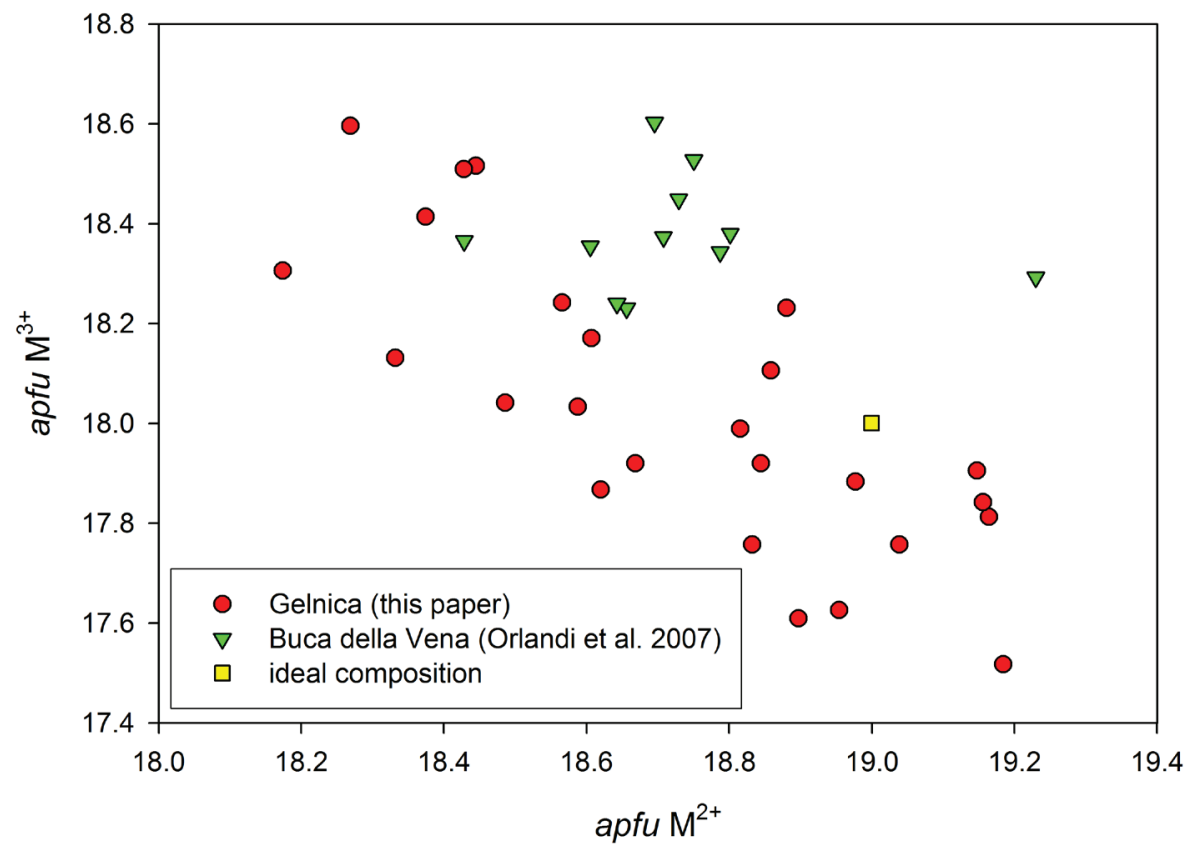

Fig. 10 Contents of divalent $(\mathrm{Pb}+\mathrm{Hg}+\mathrm{Cu}+\mathrm{Cd}+\mathrm{Fe}+\mathrm{Zn}+\mathrm{Sn})$ and trivalent $(\mathrm{Sb}+\mathrm{Bi})$ cations in marrucciite from Gelnica and Buca della Vena.

and a comparison with data published for the same mineral from Buca della Vena mine (Orlandi et al. 2007) is made in Tab. 4 and Fig. 10. The chemical composition of marrucciite from both localities is very similar. Marrucciite from Gelnica in addition contains minor amounts of $\mathrm{Bi}$ (up to 0.66 wt. \%), $\mathrm{Fe}(0.41$ wt. \%), Sn $(0.08$ wt. \%), Cd (0.07 wt. \%) and Zn (0.07 wt. \%). Interesting are regular minor contents of $\mathrm{Cl}$ (up to 0.15 wt. \% corresponding to $0.32 \mathrm{apfu}$ ) in marrucciite from both occurrences (Fig. 11). This indicates the possible presence of $\mathrm{Cl}$ in the crystal structure of marrucciite. Attempts to find its position in crystal structure using the single-crystal data collected by Laufek et al. (2007) were made, however no sensible solution was obtained. As indicated by recently published data, minor contents of specific elements (such as $\mathrm{Cl}$ or $\mathrm{O}$ ) can play a critical role in mineral formation. Examples include dadsonite (with $0.2-0.4$ wt.\% $\mathrm{Cl})$, scainiite $(0.65$ wt. \% $\mathrm{O}-$ Orlandi et al. 1999), pellouxite $(0.33$ wt. $\% \mathrm{Cl}$ and 0.39 wt. \% O - Orlandi et al. 2004), pillaite $(0.98$ wt. \% $\mathrm{Cl}$ and 0.21 wt. \% O - Orlandi et al. 2001), rouxelite $(0.20$ wt. $\% \mathrm{O}$ - Orlandi et al. 2005) or chovanite (0.06 wt. \% O - Topa et al. in print). The empirical formula of marrucciite from Gelnica, calculated from average compositions (Tab. 4) on the basis of 83 apfu is $\mathrm{Hg}_{2.93}\left(\mathrm{~Pb}_{15.63} \mathrm{Fe}_{0.08} \mathrm{Cu}_{0.04}\right.$ $\left.\mathrm{Cd}_{0.02} \mathrm{Zn}_{0.02} \mathrm{Sn}_{0.02}\right)_{\Sigma 15.81}\left(\mathrm{Sb}_{17.97}\right.$ $\left.\mathrm{Bi}_{0.04}\right)_{\Sigma 18.01}\left(\mathrm{~S}_{46.14} \mathrm{Cl}_{0.11}\right)_{\Sigma 46.25}$. This is in good agreement with the ideal formula $\mathrm{Hg}_{3} \mathrm{~Pb}_{16} \mathrm{Sb}_{18} \mathrm{~S}_{46}$ derived from the crystal structure study.

\section{Conclusions}

This paper presents description and occurrence characteristics of marrucciite from Gelnica, Slovakia. Material from this locality was described some years ago under the unapproved names "gelnicite" or "gelnicaite". Mineralogical, chemical, physical and structural data for marrucciite from Gelnica and their comparison with published data for the same mineral phase from the type locality Buca della Vena mine (Italy) are given. At Gelnica, marrucciite belongs to the youngest primary mineral phases, which originated, together with cinnabar and bournonite, during hydrothermal re-mobilization accompanying a strong tectonic activity. Because marrucciite occurs in two distinct mineral assemblages of $\mathrm{Pb}-\mathrm{Sb}$ sulfosalts, including both members with lower $\mathrm{Pb}$ con- 
tents (zinkenite, scainiite) and $\mathrm{Pb}-\mathrm{Sb}$ sulfosalts (boulangerite, bournonite), the determining factor for its origin was probably the presence of sufficient $\mathrm{Hg}$ in the source fluids.

Acknowledgements. The authors thank M. Dušek and K. Fejfarová (Institute of Physics, Academy of Science of the Czech Republic), S. Vrána (Czech Geological Survey) and V. Goliáš (Charles University in Prague) for cooperation on this research. Both referees, Emil Makovicky and Chris J. Stanley, same as handling editor Milan Novák and editor-in-chief Vojtěch Janoušek, are highly acknowledged for comments and suggestions that helped to improve the manuscript.

This paper was financially supported by the grants DE07P04OMG003 (Ministry of Culture of the Czech Republic) and VEGA grant No. 1/2028/05 (Ministry of Education of the Slovak Republic) as well as internal project of the Czech Geological Survey (No. 323000).

\section{References}

Bajaní Š (ED.) (1984) Geological map 1: 50000 of Slovenské Rudohorie Mts., Eastern part

Burnham CW (1962) Lattice constant refinement. Carnegie Inst Wash, Yearb 61: 132-135

Chovan M, Háber M, Jeleñ S, Rojkovič I (eds) (1994) Ore textures in the Western Carpathians. Slovak Academic Press, Bratislava, pp 1-219

HÁBER M (1980) Mineralogisch-geochemische und paragenetische Erforschung hydrothermaler Gänge zwischen Prakovce und Kojšov (Spišsko-Gemerské Rudohorie). Západné Karpaty, Sér Mineral Petrogr Geoch Metalog 7: 7-131

HÁBER M, BABČAN J (1971) Preliminary identification of sulfosalt $5 \mathrm{PbS} . \mathrm{HgS} .3 \mathrm{Sb}_{2} \mathrm{~S}_{3}$ and attempt on its synthesis. Miner Slov 3: 261 (in Slovak)

Háber M, Babčan J. Burke EAJ, Simonov MA, Ozdín D (2004) Gelnicaite - new sulphosalt (?) from the Zenderling occurrence near Gelnica. Natura Carpatica XLV: 229-230 (in Slovak)

Hurai V, Harčová E, Huraiová M, Ozdín D, Prochaska W, Wiegerová V (2002) Origin of siderite veins in the Western Carpathians: I. P-T $-\mathrm{X}-\delta^{13} \mathrm{C}-\delta^{18} \mathrm{O}$ relations in ore-forming brines of the Rudňany deposit. Ore Geol Rev 21: 67-101

IvANIČKA J, SNOPKo L, SNOPKOvÁ P (1989) Biostratigraphical results from eastern part of Gelnica Complex. Geol Práce Spr 89: 119-136 (in Slovak)

KoDĚRA M. (ed.) (1986) Topographic Mineralogy of Slovak Republic $-1^{\text {st }}$ part. Veda, Bratislava, pp 1-580 (in Slovak)

Kraus W, Nolze G (2000) PowderCell for Windows, version 2.4 .

Laufek F, Sejkora J, Fejfarová K, Dušek M, Ozdín D (2007) The mineral marrucciite: monoclinic $\mathrm{Hg}_{3} \mathrm{~Pb}_{16} \mathrm{Sb}_{18} \mathrm{~S}_{46}$. Acta Cryst E63, i190. doi: 10.1107/S1600536806040980

Moëlo Y, Meerschaut A, Orlandi P, Palvadeau P (2000) Lead-antimony sulfosalts from Tuscany (Italy): II Crystal structure of scainiite, $\mathrm{Pb}_{14} \mathrm{Sb}_{30} \mathrm{~S}_{54} \mathrm{O}_{5}$, an expanded monoclinic derivative of $\mathrm{Ba}_{12} \mathrm{Bi}_{24} \mathrm{~S}_{47}$ hexagonal sub-type (zinkenite group). Eur J Mineral 12: 835-546

ONDRUŠ P (1995) ZDS - software for analysis of X-ray powder diffraction patterns. Version 6.01. User's Guide. Prague, pp 1-120

Orlandi P, Moëlo Y, Meerschaut A, Palvadeau P (1999) Lead-antimony sulfosalts from Tuscany (Italy). I. Scainiite, $\mathrm{Pb}_{14} \mathrm{Sb}_{30} \mathrm{~S}_{54} \mathrm{O}_{5}$, the first $\mathrm{Pb}$-Sb oxy-sulfosalt from Buca della Vena Mine. Eur J Mineral 11: 949-954

Orlandi P, Moëlo Y, Meerschaut A, Palvadeau P (2001) Lead-antimony sulfosalts from Tuscany (Italy). III. Pillaite, $\mathrm{Pb}_{9} \mathrm{Sb}_{10} \mathrm{~S}_{23} \mathrm{ClO}_{0.5}$, a new $\mathrm{Pb}-\mathrm{Sb}$ oxy-chlorosulfosalt, from Buca della Vena mine. Eur J Mineral 13: 605-610

Orlandi P, Moëlo Y, Meerschaut A, Palvadeau P, Leone P (2004) Lead-antimony sulfosalts from Tuscany (Italy). 
VI. Pellouxite, $\sim(\mathrm{Cu}, \mathrm{Ag})_{2} \mathrm{~Pb}_{21} \mathrm{Sb}_{23} \mathrm{~S}_{55} \mathrm{ClO}$, a new oxychloro-sulfosalt from Buca della Vena mine, Apuan Alps. Eur J Mineral 16: 839-844

Orlandi P, Meerschaut A, Moëlo Y, Palvadeau P, Leone $\mathrm{P}$ (2005) Lead-antimony sulfosalts from Tuscany (Italy). VIII. Rouxelite, $\mathrm{Cu}_{2} \mathrm{HgPb}_{22} \mathrm{Sb}_{28} \mathrm{~S}_{64}(\mathrm{O}, \mathrm{S})_{2}$, a new sulfosalt from Buca della Vena mine, Apuan Alps: definition and crystal structure. Can Mineral 43: 919-933

Orlandi P, Moëlo Y, Campostrini I, Meerschaut A (2007) Lead-antimony sulfosalts from Tuscany (Italy). IX. Marrucciite, $\mathrm{Hg}_{3} \mathrm{~Pb}_{16} \mathrm{Sb}_{18} \mathrm{~S}_{46}$, a new sulfosalt from Buca della Vena mine, Apuan Alps: definition and crystal structure. Eur J Mineral 19: 267-279
Slavkay M. (ed.) (2004) Mineral Deposits of Slovenské Rudohorie Mts. 2. Monograph, State Geological Institute of Dionýz Štúr, Bratislava, pp 1-243

Topa D, Sejkora J, Makovicky E, Pršek J, Ozdín D, Putz H, Dittrich H, Karup-Møller S (in print) Chovanite, $\mathrm{Pb}_{15-2 \mathrm{x}} \mathrm{Sb}_{14+2 \mathrm{x}} \mathrm{S}_{36} \mathrm{O}_{\mathrm{x}}(\mathrm{x} \sim 0.2)$, a new sulfosalt species from the Low Tatra Mountains, Western Carpathians, Slovakia. Eur J Mineral

Yvon K, Jeitschko W., Parthé E (1977) Lazy Pulverix, a computer program for calculation X-ray and neutron diffraction powder patterns. J Appl Cryst 10: 73-74 